S. I. ANALYTIC ECCLESIOLOGY

DOI: https://doi.org/10.14428/thl.v4i1.58353

\title{
Editorial: Analytic Ecclesiology
}

JOSHUA COCKAYNE

University of St. Andrews

Ilc22@st-andrews.ac.uk

DAVID EFIRD (1974-2020)

University of York

David Efird, the co-editor of this issue, unexpectedly passed away at the beginning of this year. This issue is dedicated to his memory. "Analytic Ecclesiology" brings two important areas of David's life into conversation: analytic philosophy and the Church.

David studied for a PhD on metaphysical nihilism, under the supervision of Timothy Williamson at the University of Oxford, before taking a post at the University of York, where he remained until his death. David was an exemplary philosopher who could seemingly turn his philosophical nous to any topic or subject. He published papers on topics as varied as the metaphysics of nothingness, the experience of Christian art, liturgy, the social epistemology of deconversion amongst LGBTQ+ individuals, the metaphysics of conception, and the beatific vision. David's research interests were often directed by the conversations he had with colleagues and students; he was never afraid, after an engaging conversation on an issue, to offer to write something with that person, regardless of their level of seniority and expertise.

It was only natural, then, that in beginning his training as an ordained priest, his philosophical expertise would be turned to issues of theological and spiritual importance. David approached his faith and his ministry with the openmindedness and intrigue of an analytic philosopher; never afraid to interrogate the beliefs of the Church and always willing to help others explore their own beliefs with integrity and honesty, regardless of their particular views. The application of David's expertise to issues of ecclesiology was, therefore, a perfect fit, and he was excited to see the advances being made in this area. I think he would have been very encouraged to see the contributions made in this issue, and ready to embark on many new research projects after discussing the arguments contained herein.

Why ecclesiology? While analytic theology is still a young and emerging discipline, the lack of work on ecclesiology within this field is striking. Despite pathbreaking work on many of the core doctrines of the Christian faith, work on ecclesiology has not received the same share of attention. According to some of 
its proponents, analytic theology is committed to explicating the core claims of the Christian tradition, using the tools of contemporary analytic philosophy. ${ }^{1}$ Since belief in the "one holy, catholic, and apostolic Church" is a core doctrine of this tradition, ${ }^{2}$ it seems that analytic theologians ought to pay more attention to this important area of theology.

Indeed, there have been numerous calls to address the lack of ecclesiology in analytic theology. In Tom McCall's An Invitation to Analytic Theology, which is seen by many as the go-to introduction to analytic theology, he writes,

consider the underdeveloped areas of inquiry in ecclesiology. What is the church? Is it best understood as a four-dimensional entity? What is the relation of the "one" to the "many" in ecclesiology? What happens in the liturgy? What do we learn from the liturgy about God, Christ, sin and salvation? How should we understand the sacraments? What is the mission of the church? What happens in acts of ministry? These questions, and many more, largely await further exploration and analysis. $(2015,151-52)$

McCall is right that these questions have largely gone unasked by analytic theologians. And many of the questions McCall asks would make for excellent research questions as work in analytic theology begins to broaden and deepen.

One area that has seen some growth since McCall wrote these words is the discussion of Christian liturgy by analytic thinkers. In his address to the $40^{\text {th }}$ Anniversary of the Society of Christian Philosophy, one of the leading figures in the analytic discussion of liturgy, Nicholas Wolterstorff, reflected on the need for more work in this area and acknowledged the advances that already had taken place. In Wolterstorff's words: "I would love to see a flowering of discussion about liturgy in the next decade or two, perhaps that flowering is beginning. ... I have come myself to think that liturgy is in fact one of the most challenging and fascinating fields for philosophical inquiry." 3 The "flowering" to which he refers is exemplified by three recent books and a number of articles, penned by Wolterstorff, Terence Cuneo and a handful of others, exploring the philosophical significance of Christian liturgy. ${ }^{4}$ But as Wolterstorff's comments make clear, there is still more to be done. The essays in this special issue aim to address these

\footnotetext{
${ }^{1}$ See Chapter 1 of Oliver Crisp's Analyzing Doctrine (2019) for a fuller account of the nature of analytic theology.

2 Taken from the Nicene Creed.

3 Nicholas Wolterstorff, 'The SCP: Then, Now, and Beyond': https://www.youtube.com/watch?v=oYgFX1eN-RE

4 I summarise much of this literature in my articles, 'Philosophy and liturgy part 1: Liturgy and philosophy of action', (2018a); 'Philosophy and liturgy part 2: Liturgy and epistemology'. (2018b).
} 
under-explored themes and to continue this flowering of ecclesiological and liturgical theology in the analytic tradition.

Indeed, a number of the essays in this issue address questions related to the nature and practice of liturgy, offering a much-needed broadening of this discussion. In her essay, Faith Glavey Pawl notes the lack of interest in the analytic tradition to the issue of infant participation in liturgy and offers an insightful discussion of the importance of including children in our consideration of liturgy. Drawing from work in religious education and development psychology, Pawl offers a re-centring of the discussion which sees children as exemplary liturgical participants, serving to challenge our perspective on how we all participate in liturgy. Sarah Shin's paper seeks to bring discussions in analytic theology into conversation with another area which has largely been overlooked in the literature so far, namely, black theology. Shin explores the concept of black joy as resistance to evil. Developing recent analytic discussions of liturgy, she argues that feasting can be a group liturgical action that helps the Church to resist evil and its signatures of death, despair, and desecration of life. Another important lacuna in the analytic discussion of liturgy is in the Christian traditions which are represented by the literature. Two essays in this issue serve to fill this lacuna in very different ways. First, Joseph Blado and Tyler Dalton $\mathrm{McNabb}$ argue that we have good reasons to think that 'high church' liturgies are more able to bring about robust human flourishing than 'low church' liturgies. Building on principles found in the Confucian tradition, Blado and $\mathrm{McNabb}$ maintain that the highly ritualistic practices offered by high church liturgies mean that we have good reason to think that such traditions are necessary for the flourishing of the Church and ordained by God. Secondly, Joanna Leidenhag considers the nature of liturgy in the charismatic tradition. Leidenhag argues that recent work on group action and group ontology can help us to give an account of the nature of charismatic gifts as liturgical practices. She argues that charismatic gifts should be thought of as a kind of group action which is both scripted and improvised, thereby allowing the Holy Spirit to transform those gathered into the unified Body of Christ.

Another important area of ecclesiology which is explored in a number of essays is that of the Church's metaphysics. Three of the contributions to the issue explore the notion of the-one-and-the-many, and questions of how there can be unity in the Church despite its obvious diversity. First, Alejandro Zafeiropoulos addresses the puzzle that arises when we consider whether the claim that "the Roman Catholic Church is the Church of Christ" contradicts the claim that "the Orthodox Church is the Church of Christ". Building on work on the metaphysics of constitution in recent analytic discussions of the Trinity, Zafeiropoulos argues that there is a parallel claim made in ecclesiology, namely, that a number of Christian traditions may constitute the Church of Christ, without being 
numerically identical to it. Next, in his discussion of "multi-site ecclesiology", Jordan L. Steffaniak, asks what difference the practice of holding church services across multiple sites might make to our understanding of the metaphysics of the Church. Steffaniak argues that it is metaphysically impossible for multi-site and multi-service churches to exist as individual churches, suggesting our metaphysics should force us to see that each of these services or sites counts as a distinct church. Lastly, Bob Fischer draws from John Rawls's Political Liberalism to argue for an account that sees churches as akin to political bodies composed of reasonable citizens. Fischer's Rawlsian vision of church congregations attempts to account for the church's unity despite its vast diversity, thereby holding together principles of tolerance and inclusivity, without giving up a distinctly Christian identity.

Finally, issues of spirituality are an important component of ecclesiology but have been largely overlooked in analytic theology. One such area relates to questions of revelation and religious experience, and asks what we should conclude when God appears to be hidden. Applying work on the metaphysics of the Church and the philosophy of liturgy to the much-discussed problem of divine hiddenness can move the discussion in fruitful directions, according to Derek S. King's essay. In particular, paying attention to Gregory of Nyssa's work helps us to see that the Church is the primary location of Christ's revelation in the world, showing that many of the assumptions made by the hiddenness argument are not well formed. Another issue of spiritual importance, largely missing from analytic discussions, is that of spiritual formation. Jeremy M. Rios shows that there is a lack of consensus about what spiritual formation is and argues that applying an analytic approach to this area would help to clarify this important issue. Rios's account aims to specify the subject of formation (the person), the verb of formation (passive and intransitive), and the indirect object of formation (a given telos). Drawing from discussions of Family Systems Theory, Rios argues that since persons are complex, irreducible, and communal, the process of formation must be grounded in environment, ritual, and worship. The indirect object of this process, according to Rios, must be the image of the Triune God.

I hope these essays serve to continue the expansion of analytic theology to areas of vital theological importance and spark many more conversations on questions related to the Church in the near future. And, perhaps, we should all be a little bolder in following David Efird's lead to take the opportunities afforded in discussing these papers to offer invitations of our own - who knows where these collaborations may lead. ${ }^{5}$

\footnotetext{
${ }^{5}$ This issue was in part made possible thanks to the generous funding of the Templeton Religion Trust.
} 


\section{Bibliography}

Cockayne, Joshua. 2018a. "Philosophy and liturgy part 1: Liturgy and philosophy of action." Philosophy Compass 13, 10. https://doi.org/10.1111/phc3.12547.

Cockayne, Joshua. 2018b. "Philosophy and liturgy part 2: Liturgy and epistemology." Philosophy Compass 13, 10. https://doi.org/10.1111/phc3.12522.

Crisp, Oliver D. 2019. Analyzing Doctrine: Toward a Systematic Theology. Texas: Baylor University Press.

McCall, Thomas H. 2015. An Invitation to Analytic Christian Theology. Downers Grove: InterVarsity Press.

Published Online: September 1, 2020 